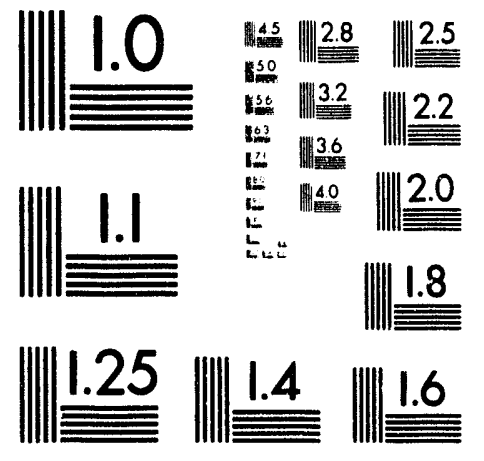



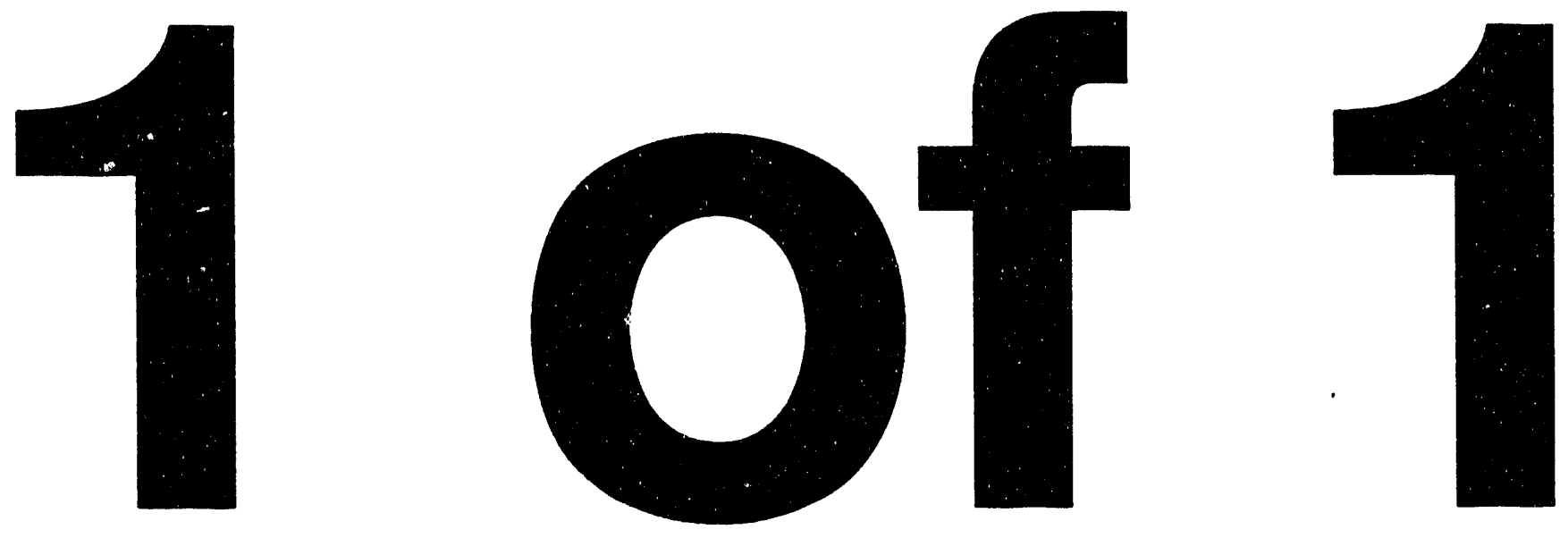
Rawlins UCG Demonstration Project

FINAL

TECHNICAL PROGRESS REPORT

FOR THE PERIOD

JANUARY 1, 1987 - FEBRUARY 9, 1988

August 3, 1988

\author{
Prepared in Support of \\ U.S. Department of Energy \\ Cooperative Agreement No. DE-FC21-88MC24167
}

\author{
Energy International, Inc. \\ 135 William Pitt Way \\ Pittsburgh, PA 15238 \\ EI Report No. 0788-017
}

\title{
DISCLAIMER
}

This report was prepared as an account of work sponsored by an agency of the United States Government. Neither the United States Government nor any agency thereof, nor any of their emfiloyeses, makes any warranty, express or implied, or assumes any legal liability or responsibility for the accuracy, completeness, or usefulness of any information, apparatus, product, or process disclosed, or represents that its use would not infringe privately owned rights. Reference herein to any specific commercial product, process, or service by trade name, trademark, manufacturer, or otherwise does not necessarily constitute or imply its endorsement, recommendation, or favoring by the Unitad Siates Gurernment or any a aéency theteour. The viewis and opinions of authors expressed herein do not necessarily state or reflect those of the United States Government or any agency thereor. 
TABLB OF CONTENTS

I. INTRODUCTION • . . . . . . . . . . . . . . . . . 1

II. ACTIVE PROJBCT TASKS

1.0 Phase I - Design and Permitting

1.1 Project Integration . . . . . . . . . 2

1.2 Technical Support . . . . . . . . . . . 4

1.3 Environmental, Heaith, Safety and

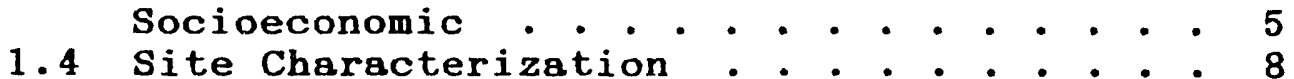

1.5 Process Well Design .. . . . . . . . . 14

1.6 Surface Facility Design . . . . . . . . . 15

1.7 Resource Acquisition . . . . . . . . . . 18

1.8 Preliminary Site Civil . . . . . . . 19

III . SUMMARY . . . . . . . . . . . . . . . . . . 20 


\section{TAOLB OF TABLES}

1.4.1 Drilling Program Summary . . . . . . . . . . . 10

1.4.2 Hydrology Monitoring Well Completion Data . . . . 14 
TABLB OF FIGURBS

1.4.1 Location Map for Phase I Drilling . . . . . . . . . . 11

1.4.2 Well Completion for Deep Wells . . . . . . . . . . . 12

1.4.3 Well Completion for Shallow Wells . . . . . . . . . 13 


\section{INTRODUCTION}

The U.S. Department of Bnergy, Clean Coal Projects Division and Bnergy International, Inc. have entered into a Cooperative Agreement to conduct a cost-shared proof-of-concept (POC) field test demonstrating the operation of commercial-scale steeply dipping bed underground coal gasification (UCG) modules to provide the synthesis gas for a small-scale commercial ammonia plant. The field test and the commercial ammonia plant will be located near Rawlins, Wyoming. During this demonstration test, tro or more UCG modules will be operated simultaneously until one module is completely consumed and an additional module is brought on line. During this period, the average coal

gasification rate will be between 500 and 1,200 tons per day. A portion of the raw UCG product gas will be cleaned and converted into a synthesis gas, which will be used as feedstock to a 400-500 ton per day ammonia plant. The UCG facility will continue to operate subsequent to the POC demonstration to provide feedstock for the commercial plant. Bnergy International is responsible for accomplishing specific objectives in accordance with the Statement of Work by designing, installing, operating and monitoring the performance of the UCG modules as the feedstock source for the small-scale commercial ammonia plant.

This Technical Quarterly Report covers the entire period from project start (January 1, 1987) to February 9, 1988. Although DOB participation in the project did not officially begin until Novemnber 9, 1987, BI started the project on January 1, 1987, and is including the pre-DOB involvement activities in this report to provide a better overall picture of the project. Most of the project activities have focused on project structuring, financing and design activities. Baseline studies for the mining permit were also conducted during this period. 
II. ACTIVE PROJECT TASES

1.0 Phase I - Design and Permitting

1.1 Project Integration

The Cooperative Agreement between Bnergy International, Inc. (BI) and the Department of Bnergy was signed by BI on September 30, 1987. The agreement was submitted to Congress on November 9,1987 and signed by $\mathrm{DOB}$ on December 23, 1987. Invoices have been submitted to DOB for its share for project work performed as of November 9,1987 .

Procedures for Accounting and Procurement have been finalized. These procedures will become a part of the Project Management Plan. Accounts are organized using the WBS schedule. The accounting system is in accordance with CAS (Cost Accounting Standards) and GAAP (Generally Accepted Accounting Principles). Bnergy International is preparing for an audit by DCAA (Defense Contractors Audit Agency) which is expected to occur in the near future.

The legal structuring of the project is continuing and will be finalized at the time the project financing is complete. This is expected to occur in the next 120 days.

During 1987, financing for Phase $I$ was obtained from Venture Pacific Limited, a shareholder in Bnergy International, Inc. Commitment letters were obtained from PNC Corporation for the total financing of the project. Bnergy International is proceeding to meet the conditions set forth in the commitment letters. Completion of engineering and obtaining an acceptable construction bid are essential elements to agreement of the financial package.

Procurement procedures were revised and have been adopted as Corporate Policy No. B-1. On January 26, 1988, this Policy \& Procedure was sent to DOB's Contracting officer for review and consent.

During the 13 month period from January 1, 1987 to February 9, 1988, several purchase orders were awarded for work included in site characterization, BHSS and process design related work. The contracts were awarded for the following:

- drilling service

- management of site characterization

- hydrologic consultation 
Bfforts were made whenever possible to competitively bid all work. In some cases this was not possible or desirable. Sole source justifications have been written for the cases where the work was not competitively bid.

Energy International has received a resolution from the Wyoming State Land Board at their January 7, 1988 meeting to provide State royalty gas to the project as a back-up supply to the Ammonia Plant in the unlikely event that the UCG process fails to meet gas quality required for ammonia manufacturing. This "back-up" supply is critical to the project financing.

Work is progressing on the marketing of the ammonia. Several buyers have been jdentified and negotiations are proceeding.

The Project Management Plan was due on December 9, 1987 as a deliverable to DOB under the Cooperative Agreement. This will be submitted early in the next quarter. Submittal of this report is delayed due to required information on the project financing. The Project Evaluation Plan was due on February 7 , 1988. This document also required financing information and will be submitted during the next quarter. 


\subsection{Technical Support}

The conceptual design task is $80 \%$ complete at this time. Total completion is scheduled for the end of the first quarter of 1988. From the conceptual design information, the Facility Design Criteria document has been written. It defines the general parameters and conditions for the project and the facilities. This includes such factors as site location and cunditions, approximate unit capacities and service factor, coal specifications, UCG design criteria, UCG gas compositions, general description of the process and utility plants, environmental criteria, and safety standards. This information was incorporated into a Project Scope Book which also included process flow diagrams for the several process and utility plants. Preliminary energy and material balances and geotechnical data were also included.

The conceptual design information will be incorporated into a Conceptual Design Report which is a deliverable to DOB under the Cooperative Agreement. The Conceptual Design Report and the 40\% Design Review Package were due on February 15, 1988. The Conceptual Design Report will be delayed to incorporate possible scope changes. The $40 \%$ Design Review information will be sent to DOB as it becomes available. 


\subsection{Environmental, Health, Safety and Socioeconomic}

The Rawlins UCG Demonstration Project is required to comply with the National Environmental Policy Act. As a part of this requirement, Bnergy International was required to submit an Environmental Report to DOB for review. This report was submitted to DOB in draft form in April of 1987. The Final Environmental Report was submitted to DOB February 2, 1988. Oak Ridge National Laboratories (ORNL) was contracted by DOB to prepare an Bnvironmental Assessment for the project. Bnergy International was required to interface with DOB and ORNL in the form of providing supplemental information and attendance at site visits and meetings. The Bnvironmental Assessment was submitted to DOB in December of 1987 from which DOB prepared a Finding of No Significant Impact. Bnergy International is awaiting final approval of NEPA compliance.

Baseline environmental data collection began in May of 1987 and is continuing to the present time. Most of the baseline data collection is required for the In Situ Mining Permit.

Baseline wildlife studies were conducted on the site during May of 1987. This activity was mainly initiated to gather baseline information on the Ferruginous Hawk, prairie dogs, and sage grouse, a species of state interest.

The Ferruginous Hawk is a species on the list of Migratory Birds of High Federal Interest (MBHFI). The project site and lands adjacent to the site are important nesting territories for the Ferruginous Hawk. A Monitoring and Mitigation Plan has been developed which will provide for the maintenance and enhancement of the population. This plan was developed in conjunction with the Wyoming State Game and Fish Department, the United States Fish and Wildlife Service (U.S.F.W.S.), the Bureau of Land Management (BLM) and the Hyoming Department of Environmental Quality (WDBQ). The plan calls for the establishment of ten artificial nesting territories to be installed within three miles of the project site and field monitoring of the species prior to and during the nesting season. - 
Locations of prairie dog colonies were mapped separately by the project and by the BLM. Prairie dogs are the main prey base for the North American Black Footed Ferret, a species which is on the Bndangered Species List. The U.S.F.W.S. requirements call for Ferret clearances at any location where there are sufficient prairie dog colonies to support Ferrets. A Ferret clearance was conducted on the project site during July of 1987 and no ferrets were found. Official clearance has been given by the U.S.F.W.S. for construction on the site.

A vegetation and soils survey was conducted on the site in accordance with the guidelines set forth by WDEQ. Soil and vegetation maps have been constructed and will be submitted with the mining permit.

An archeological survey was conducted on the site area. Three potential sites were found. It was determined that the best way to mitigate the effects of the project on these sites was to fence them. All three sites have been fenced.

Baseline water sampling has not been conducted during this reporting period but will be performed during the next quarter. Bighteen hydrologic monitoring wells have been installed and will be sampled.

Several permits have been either obtained or investigated during this reporting period. Most permits are required by the regulating agency which is WDEQ.

The Air Quality Permit-to-Construct application was submitted to the WDEQ/Air Quality Division on October 30, 1987. It has been through a completeness review and is now in the technical review period. It is scheduled to go into public comment during April and will be granted during May. This permit is required before construction of the facility can begin.

The Site Characterization Program was performed under a Coal Notification of Intent to Bxplore for Coal by Drilling which was filed with the WDEQ/Land Quality Division. It carries a bond for surface and well reclamation. This notification will be completely absorbed into the In-Situ Mining Permit when it is granted. 
Baseline studies are complete for the submission of the In-Situ Mining Permit application with the exception of the baseline hydrological monitoring. It is expected that the permit application will be submitted during May of 1988. This permit is required before construction of the UCG wellfield commences.

Work on the health and safety aspects of the program is being conducted in conjunction with the Bnvironmental Monitoring Plan Outline. This work will proceed as the Bnvironmental Monitoring Plan is developed.

Work is progressing on the socioeconomic aspects of the project. Most of the work being performed deals with the state and local government agencies on the socieconomic aspects of the projects, mainly keeping them informed. 


\subsection{Site Characterization}

The drilling program being conducted at the project site utilizes both conventional rotary and core drilling practices. Table 1.4.1 is summary of the drilling that is completed or is underway, and Figure 1.4. displays the location of the drill-holes. The drilling program was designed to satisfy two goals:

1. drill enough hcles to allow a statistically valid sampling of the target coal seams and the enveloping rock package so that a detailed geologjc model can be developed that provides an understanding of the subsurface geologic system in enough detail to allow the environmentally sound, efficient, and economic usage of the coal resources.

2. provide drill holes reaching total formation depth that have to be completed for the hydrologic monitoring program.

To date, 23 holes have been completed and one is presently being drilled. The completed drilling totals 20,323 feet. Seven of the 24 holes are solely for the purposes of collecting geological data; and the remaining 17 will be completed as hydrologic monitoring wells. Six of the hydrologic monitoring wells were dual-purpose in that cores were taken from the target coal seams before the holes were reamed and cased for hydrologic: monitoring.

During drilling of each hole, all cuttings and cores were carefully collected, described and preserved. The detailed descriptirns of the cuttings or cores were then used to produce detailed lithology logs. In addition to the descriptive logs, a sophisticated suite of geophssical logs were run downhole after total depth was reached. This suite includes: gamma-ray, neutron, long deviation survey, caliper, and temperature logs. All data is recorded in digital form and can be manipulated using standard data base programs available for micro-computers. All of the data from the geophysical logs and the descriptive lithology logs have been plotted at the same scale so that correlation of the logs is facilitated.

A primary goal of the program is to characterize coal quality of the $G$ and $I$ seams. Thirteen cores have been taken from the $G$ seam and nine ave been taken from the I seam. Preservation of 
the moisture content and light hydrocarbons is accomplished by immediately bagging the samples in polyethylene bags. The bags remain sealed until the sampling is to be done. At that time, the bag is opened and the core is immediately sawn in half. One half is immediately rebagged and labeled for submission to the analytical laboratory

The other half is described in detail and a sample and coal description $\mathrm{log}$ is constructed for each core. An average of 14 samples are taken from cores of the $G$ seam, and 10 are taken from I seam cores. Over 150 samples have been submitted for proximate, ultimate, ash fusion, and ash chemistry analyses.

Sampling width is determined by careful examination of the short-spaced density log and determining natural lithologic breaks. The density log is then correlated with the core and the sample is cut accordingly. This process will allow for development of a geologic framework in which the geochemistry of the coal can be inserted. Through quantitative and qualitative comparison of the geophysics and geochemistry, a relation of the geophysical response to coal quality can be established. As future exploration takes place, much of the coal quality values can be determined by use of cuttings and geophysical logging.

Hydrologic testing has not begun, but completion of the wells for the testing has been initiated. The hydrology wells are given names corresponding to either the upper sand (U), lower sand (L) or the G seam (G). Some wells show dual names on the tables which indicates the geologic characterization name as well as the hydrologic name. Completion of the holes for hydrologic monitoring entails positioning a permanent down-hole packer assembly over the interval to be tested. Table 1.4 .2 relates the pertinent information regarding casing depth and status of monitoring well completion. A well completion diagram is shown in Figures 1.4 .2 and 1.4 .3 .

Integration of the geologic, geophysical, geochemical, and hydrologic data is the prime goal of the site characterization task. This will be accomplished by developing a structural and stratigraphic model that will act as a framework in which the geochemical and hydrologic data can be placed. Integration of this data will not begin until after the drilling program is finished; but preparation for integration has begun. This includes developing a computerized data-base system in which location, stratigraphic, structural and geochemical data can be placed. Data is being placed in the data files as it becomes available. 


\begin{tabular}{|c|c|c|c|c|c|}
\hline $\begin{array}{l}\text { COMP. } \\
\text { HOLE HO. }\end{array}$ & & $\begin{array}{l}\text { DATE } \\
\text { SPUDDED }\end{array}$ & $\begin{array}{l}\text { DATE DRLNG } \\
\text { COMPLETED }\end{array}$ & $\begin{array}{l}\text { DRILLING } \\
\text { METHOD }\end{array}$ & $\begin{array}{l}\text { COAL SEAMS } \\
\text { INTERCEPTED }\end{array}$ \\
\hline RC1/U1 & * & $10-$ Nov-87 & $02-D e c-87$ & rotary & G \& I seam \\
\hline L1 & & $24-J a n-88$ & $31-J a n-88$ & rtry/core & G seam \\
\hline G2 & & $02-J a n-88$ & $12-J \operatorname{an}-88$ & rotary & G seam \\
\hline $\mathrm{RC} 6 / \mathrm{U} 2$ & $*$ & $03-D e C-87$ & $18-D e c-87$ & rtry/core & none \\
\hline L2 & & $13-D e C-87$ & $02-J a n-88$ & rotary & G \& I seam \\
\hline G3 & & $26-J \operatorname{an}-88$ & $21-J a n-88$ & rotary & G seam \\
\hline U3 & & $27-\operatorname{Jan}-88$ & $29-J a n-88$ & rotary & none \\
\hline L3 & * & $20-J \operatorname{an}-88$ & $25-J a r:-88$ & rtry/core & $G \&$ I seam \\
\hline G4 & & $23-\operatorname{Dec}-87$ & $27-\operatorname{Dec}-37$ & rotary & G sean \\
\hline U4 & & 27-Dec-87 & $29-D e c-87$ & rotary & none \\
\hline 14 & * & 20-Dec-87 & 22-Dec-87 & rtry/core & G seam \\
\hline G7 & & 10-Dec-87 & $13-D e c-87$ & rotary & G seam \\
\hline U7 & & $05-D e C-87$ & $09-D \theta C-87$ & rotary & none \\
\hline L7 & & $14-D \theta C-87$ & $18-D e C-87$ & rotary & G seam \\
\hline 57 & & $18-$ Dec-87 & 20-Dec-87 & rotary & none \\
\hline$R C 2 / U 5$ & * & $05-\operatorname{Jan}-88$ & $20-J a n-88$ & rtry/core & G \& I seam \\
\hline C5/G8 & * & $31-\operatorname{Jan}-88$ & drilling & core & G \& I seam \\
\hline
\end{tabular}

TOP CORED BTTM CORED TOTAL CORED INTERVAL INTERVAL INTERVAL

$\begin{array}{rr}1,250 & 1,554 \\ 1,060 & 1,273 \\ \text { none } & \text { none } \\ 1,050 & 1,153 \\ \text { none } & \text { none } \\ \text { none } & \text { none } \\ \text { none } & \text { none } \\ 20 & 602 \\ \text { none } & \text { none } \\ \text { none } & \text { none } \\ 192 & 270 \\ \text { none } & \text { none } \\ \text { none } & \text { none } \\ \text { none } & \text { none } \\ \text { none } & \text { none } \\ 752 & 1,205 \\ 39 & \text { drilling }\end{array}$

304
213
none
103
none
none
none
582
none
none
78
none
none
none
none
453
driting

TOTAL ROTARY FOOTAGE

TOTAL CORED FOOTAGE

TOTAL FOOTAGE DRILLED
TOTAL DEPTH

1,554

1,375

1,390

1,153

1,594

172

81

602

96

120

287

878

792

980

221

1,205

drilling

10,767

1,733

12,500

GEOLOGIC CHARACTERIZATION DRILL HOLES

\begin{tabular}{|c|c|c|c|c|c|}
\hline $\begin{array}{l}\text { COMP. } \\
\text { HOLE NO. }\end{array}$ & & $\begin{array}{l}\text { DATE } \\
\text { SPUDDED }\end{array}$ & $\begin{array}{l}\text { DATE DRLNG } \\
\text { COMPLETED }\end{array}$ & $\begin{array}{l}\text { DRILLING } \\
\text { METHOD }\end{array}$ & $\begin{array}{l}\text { COA!. SEAMS } \\
\text { INTERCEPTED }\end{array}$ \\
\hline G5 & + & 29-Dec-87 & $05-J a n-88$ & rtry/core & G seam \\
\hline G6 & + & $20-\operatorname{Jan}-88$ & $29-\operatorname{Jan}-88$ & rtry/core & G seam \\
\hline RC3 & & $12-J a n-88$ & $20-J a n-88$ & rtry/core & $G \& I$ seam \\
\hline c1 & & $29-J a n-88$ & $02-F e b-88$ & core & $G$ \& I seam \\
\hline C2 & & $05-$ Nov -87 & 17-Nov-87 & core & $G \& I$ seam \\
\hline C3 & & 28-Jan-88 & $03-F a b-88$ & core & G \& I seam \\
\hline C4 & & $18-$ Nov-87 & $05-D e c-87$ & core & $G \& I s \theta$ \\
\hline
\end{tabular}

7 HOLES DRILLED
TOP CORED BTTM CORED TOTAL CORED INTERVAL INTERVAL INTERVAL

$\begin{array}{rr}200 & 853 \\ 1,041 & 1,618 \\ 631 & 1,213 \\ 42 & 814 \\ 22 & 1,264 \\ 21 & 701 \\ 43 & 1,293\end{array}$

TOTAL ROTARY FOOTAGE TOTAL FOOTAGE CORED TOTAL FOOTAGE DRILLED
TOTAL DEPTH

1,618

1,213

814

1,264

701

1,293

2,000

5,756

7,756

DRILLING PROGRAM GRAND TOTALS

24 HOLES DRILLED

TOTAL ROTARY FOOTAGE

12,767

TOTAL FOOTAGE CORED

7,489

TOTAL FOOTAGE ALL HOLES

20,258

\section{EXPLAHATION:}

* indicates a drill hole from which cores were taken, but wass subsequently reamed and completed as a hydrologic monitoring well.

+ indicates a planned a hydrologic monitoring well that was not needed, so it was not reamed or cased. 


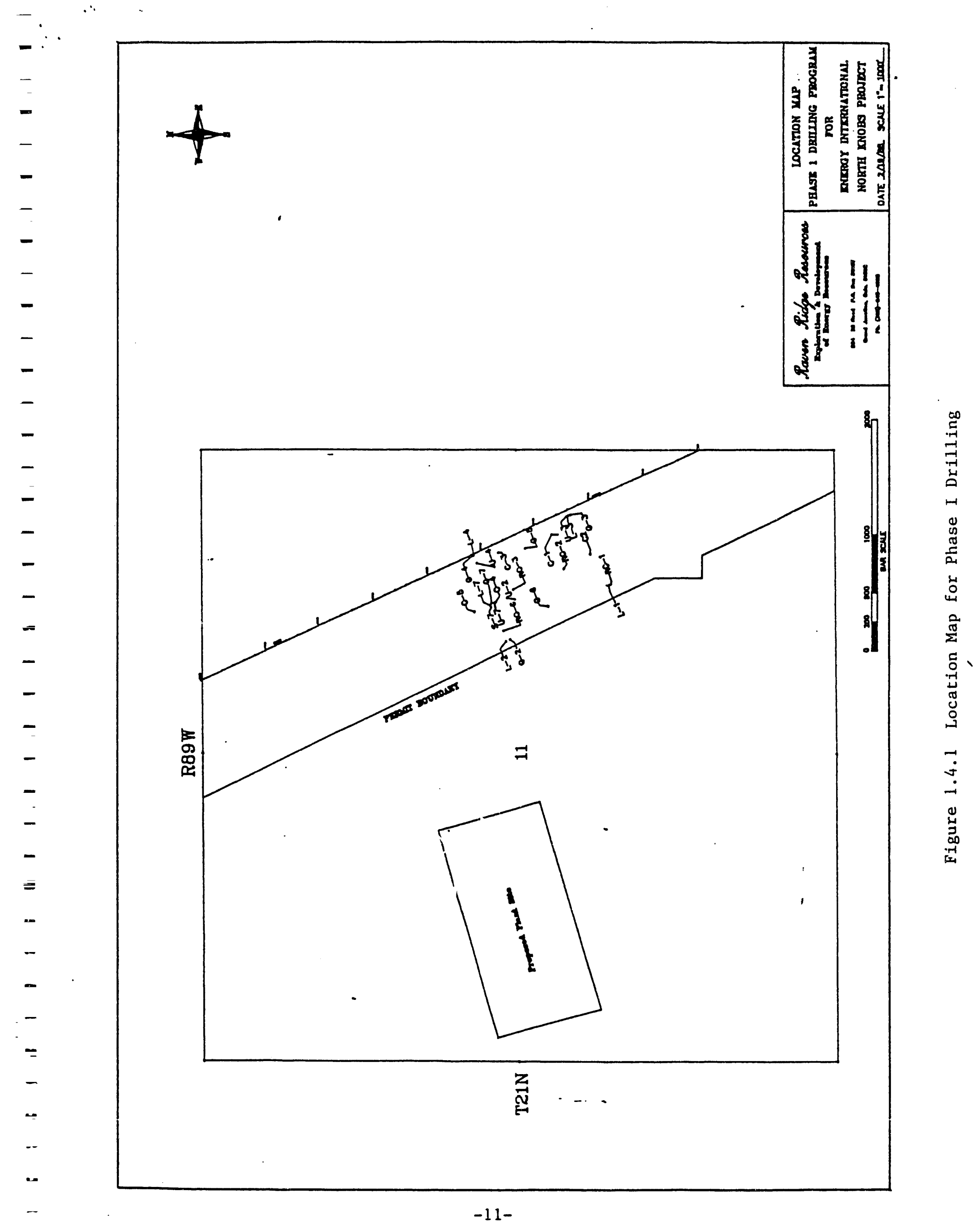


Figure 1.4.2

Generalized Well Completion for Deep Wells.

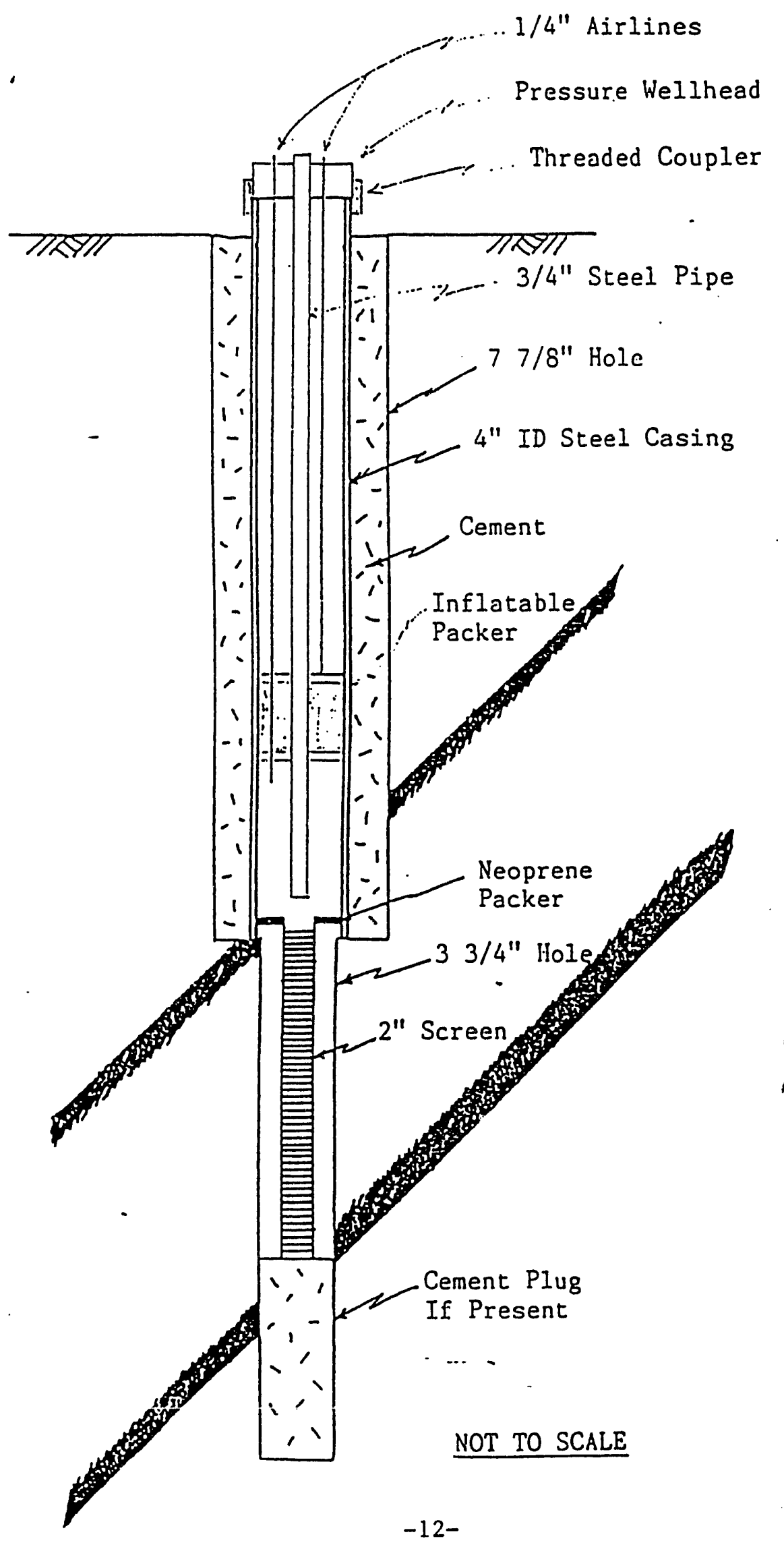


Figure 1.4.3

Generalized Well Completion for Shallow Wells.

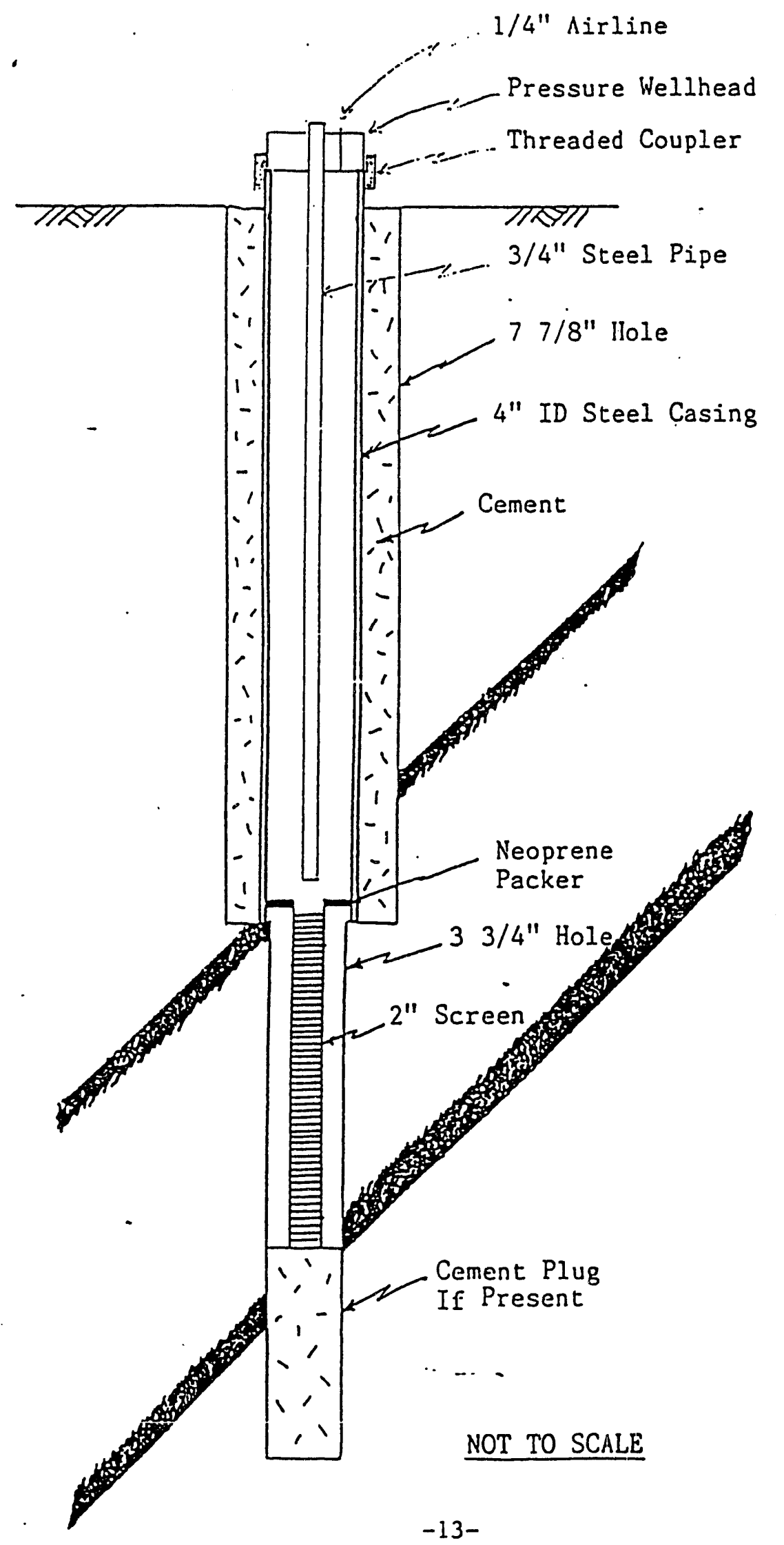


HYDROLOGY MONITORINO WELLS

\begin{tabular}{|c|c|c|c|}
\hline \multirow[t]{2}{*}{$\begin{array}{l}\text { HOLE } \\
\text { NO. }\end{array}$} & $\begin{array}{l}\text { DATE SCREEN } \\
\text { INSTALLED }\end{array}$ & $\begin{array}{l}\text { DRILLING } \\
\text { METHOD }\end{array}$ & $\begin{array}{l}\text { COMPLETIOI } \\
\text { ZONE }\end{array}$ \\
\hline & \multicolumn{3}{|c|}{ 6 } \\
\hline$R C 1 / U 1$ & 29-DeC-B7 & rotary & upper ss \\
\hline & $\begin{array}{l}-F g b-88 \\
-J a n-88\end{array}$ & $\begin{array}{l}\text { rtry/coro } \\
\text { rotary }\end{array}$ & $r s s$ \\
\hline RCB/U2 & 20-Dec-87 & rotary & upper ss \\
\hline & $02-J a n-88$ & rtry/core & lower 98 \\
\hline G3 & $28-J$ an- 88 & rotary & G seam \\
\hline U3 & 29-Jan-88 & rotary & upper ss \\
\hline L3 & $29-J a n-88$ & rtry/core & lower ss \\
\hline G4 & $28-D e C-87$ & rotary & G seam \\
\hline 44 & $29-D e C-87$ & rotary & upper ss \\
\hline L4 & $28-$ Dec-87 & rtry/core & lower gs \\
\hline G7 & $03-5-88$ & rotary & G seam \\
\hline U7 & $43-87$ & rotary & upper 99 \\
\hline$L 7$ & $-085-87$ & rotary & lower ss \\
\hline & $2 /-D e C-87$ & rotary & st \\
\hline RC2 & $21-J 2 n-88$ & rtry/core & upper $\mathbf{3 8}$ \\
\hline
\end{tabular}

DEPTH BOTTOM LENGTH 3/4" 4 1/2" CASING PIPE

1,124
1,279
1,322
1,118
1,518
104
38
238
20
104
193
819
778
907
108
717

DEPTH TO TO PACKER

1,114
1,278
1,310
1,111
1,518
97
37
247
88
101
189
812
773
895
107
708

$\begin{array}{rr}1,051 & 1,119 \\ 1,194 & 1,283 \\ 1,226 & 1,315 \\ 1,048 & 1,116 \\ 1,433 & 1,523 \\ \text { none } & 102 \\ \text { none } & 42 \\ \text { none } & 252 \\ \text { none } & 23 \\ \text { none } & 106 \\ \text { none } & 194 \\ 749 & 817 \\ 710 & 778 \\ 832 & 900 \\ \text { none } & 112 \\ 845 & 713\end{array}$

1,129

1,383

1,380

1,151

1,593

172

77

312

93

121

289

877

788

985

222

754
FOOTAGE SCREENIED 


\subsection{Process Well Design}

Process well conceptual design is underway. Bach module will include five process wells; four injection wells and one production well. Two of the injection wells will be drilled and cased to the 800 foot level and the other two injection wells will be drilled and cased to the 1200 foot level. The single production well will be drilled and cased to the 400 foot level and then drilled along the coal seam to the 1200 foot level providing an open borehole for the transport of the hot gases.

All process wells will be drilled with surface casing cemented in place. The size of the drillholes will be based upon the conditions of the injection and production gases, taking into account pressure drop and velocity. The casing will be API steel casing with buttress thread and collar connections. High temperature cement will be used where it is necessary.

Process well design includes investigating methods of directional drilling. During the steeply dipping bed testing, slant drilling was used. By using medium radius drilling, the well lengths can be much shorter and therefore will represent a cost saving. The wells will also be drilled as close as possible to each other at the surface to minimize surface piping in the wellfield. 


\subsection{Surface Facility Design}

Bnergy International selected ammonia as the most economically attractive product to be produced from UCG synthesis gas. This decision was based on current and projected markets and prices for the various products that could be produced from UCG gas generated in Rawlins, WY. This UCG to Ammonia project will meet the criteria of Proof of Concept for the DOB, and be commercially viable while being environmentally acceptable.

Process parameters and plant size have been established during this reporting period. An existing ammonia plant in-the 300-450 TPD range was selected to be optimum for this UCG demonstration project. This size of plant is large enough to provide proof of concept for UCG technology and to generate a revenue stream capable of covering fixed labor costs.

An oxygen plant of 250-400 TPD has been located to supply oxygen for the UCG and ammonia operations. Two co-generation units have been identified which will produce 13-25 megawatts of power for the oxygen plant and other units depending on final configuration economics. Co-generation was not in the original plan but is being considered because it may be less expensive than bringing conventional power to the site. BI will be formally notifying DOB of this modification and requesting permission for a scope change.

The decision was made to relocate used plants. New plants smaller than world scale, 100-1599 TPD for ammonia have poor economics. The relocation of shutdown chemical plants has become an accepted practice since the late $1970^{\prime} \mathrm{s}$ and several used small ammonia plants are available for purchase and relocation. 
Four ammonia facilities in the 300 to 600 TPD production range pere identified and inspected. The selected plant is a 420 TPD Columbia Nitrogen Corporation plant in Augusta, GA. This plant was selected for the following reasons:

- price, and the lack of a primary reformer which is unnecessary when operating with UCG synthesis gas.

- gas engined compressors which will not require a large electrical load and could be fueled with treated UCG product gas.

- high turn-down ratio and single unit facility.

- history of good operations, excellent maintenance programs and domestic location.

An option has been obtained on this unit and a purchase agreement will be finalized prior to the end of Phase I activities.

Five oxygen plants in the 250-400 TPD production range were identified and inspected. The selected plant is a 360 TPD Union Carbide plant at Sault Saint Marie, Ontario. This plant was selected for the following reasons:

- price, and included a liquid storage sphere.

- history of good operation and maintenance programs.

- located conveniently for relocation to Wyoming on the USA and Canadian borders.

An option was obtained on this unit and a purchase agreement will be finalized prior to the end of Phase II activities.

Several co-generation units were identified through Rockware Corporation, who specializes in remanufacturing and relocating used gas turbine, co-generation units. Many units are available in the 8 to 13 megawatt range (adjusted for 7000 foot elevation of Rawlins, WY). The final selection will depend on the energy balances for the toal facility. Current evaluations support the use of two 13 megawatt units. 
Fluor-Daniel was selected to prepare preliminary engineering designs for the entire project. The following work has been completed:

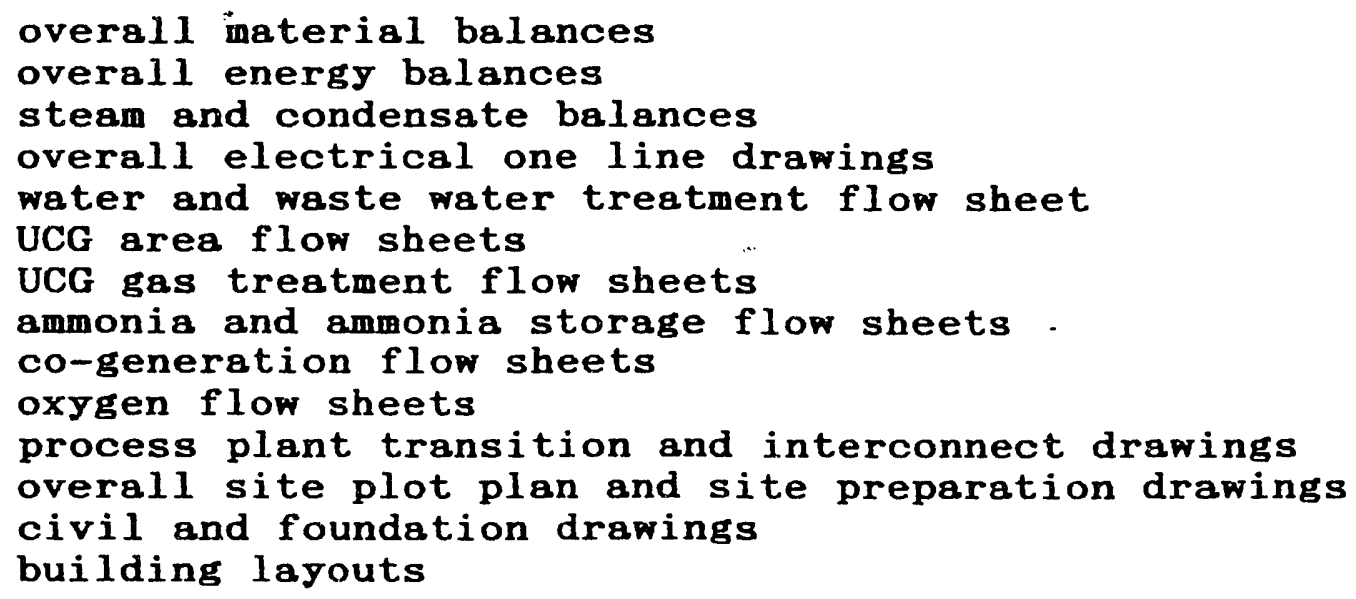

Work is continuing in this area as activities begin in the area of detailed design. 


\subsection{Resource Acquisition}

The resource acquisition task includes securing the coal lease, rights-of-way for access, process water, and power. Although some of these activities are not yet complete, the negotiations are well underway.

A coal licensing agreement has been executed with Union Pacific Resources Company which leases the coal and surface on Sections 11 and 13 north of I-80 to Energy International. The term of the lease is for 10 years or until the project is terminated.

Several rights-of-way will be required for site access and pipeline corridors. The rights-of-way for access to the site through the BLM sections has been secured. Site access for the Union Pacific sections has been applied for. No rights-of-way for pipeline corridors has been applied for because the route has not yet been surveyed due to bad weather.

Negotiations are in progress with the City of Rawlins to purchase process water and with Pacific Power and Light to purchase power. 


\subsection{Preliminary Site Civil Preparation}

To date, the only activities in this task have been minimal grading of the access roads. This was done to allow site characterization drilling traffic to enter the site. 


\section{SUMAARY}

Department of Energy Participation in the Rawlins UCG

Demonstration Project began officially on November 9, 1987. Bven though their financial participation began at this time, they will receive technical information from the start of the project which was on January $1,1987$.

The Rawlins UCG Demonstration Project is progressing in Phase I with the majority of the emphasis on facility design, site characterization and the environmental work. The site characterization field work is estimated to be completed by the end of February with the final report completion towards the end of Phase I. The facility design effort is close to the $40 x$ level. It is anticipated that all permits will be applied for in Phase $I$ and most of them will be granted by the end of Phase I.

The obtaining of the private financing continues to be a major activity in the project. All of the financing must be in place before the continuation for DOB funding to Phase II will be applied for. 

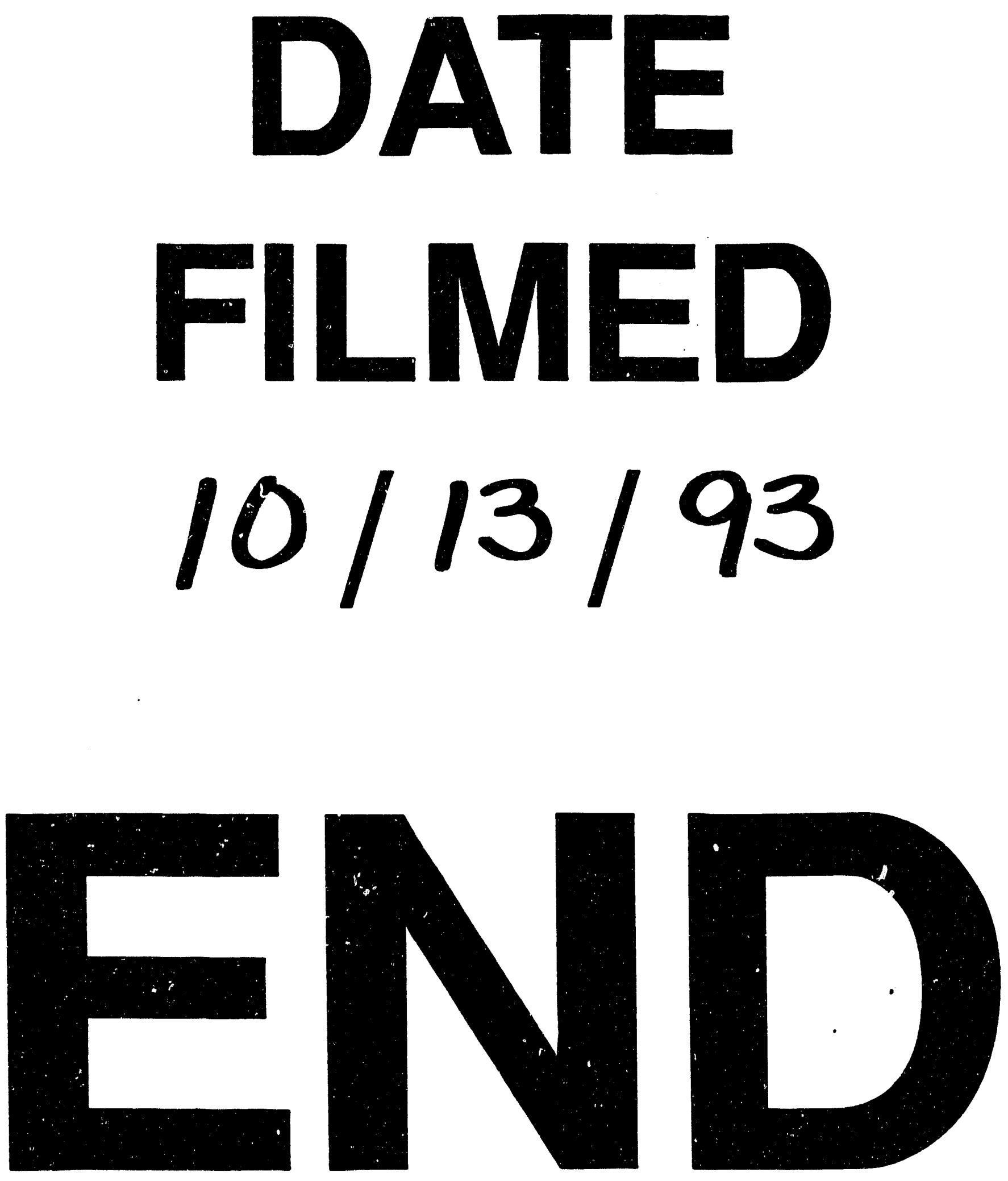
